\title{
Teachers' Willingness about the Use of ICT through M-Learning in Pakistan
}

\author{
Shafaq Salam ${ }^{1}$, Mengke Yang ${ }^{2}$, Mahmood Movahedipour ${ }^{3}$ and Jianqiu Zeng ${ }^{4}$ \\ ${ }^{1,3,4}$ School of Economics and Management, Beijing University of Posts and \\ Telecommunication, Beijing, 100876, P. R. China. \\ ${ }^{2}$ School of Automation, Beijing University of Posts and Telecommunications, \\ Beijing, 100876, P. R. China. \\ ${ }^{1}$ shafaqsalam@yahoo.com, ${ }^{2}$ yangmengke@139.com, \\ ${ }^{3}$ mahmood.movahedipour@yahoo.com, ${ }^{4} 13718688489 @ 139 . c o m$
}

\begin{abstract}
The benefits of Information and Communication Technologies (ICT) in the education sector of developed countries are well known and well established. It has brought a complete change to the traditional educational system. However, there are many challenges in developing countries in order to reap the perceived benefits. One of the main challenges is the acceptance of change. The use of ICT in public schools of Khyber Pakhtunkhwa (KP) province of Pakistan is a challenging task. The main reason is the lack of interest due to its complexity in learning the use of computer by the public school teachers. The purpose of this study is to investigate the willingness and perception of public school teachers of KP province of Pakistan about the use of ICT through mobile learning (m-learning). The motivation behind this work is the increasing popularity and acceptance of smart phones among common people. This research conducted a survey with 524 public school teachers. The results indicate that teachers in KP province are willing to acquire ICT training through m-learning. Financial constraints related to the use and acquiring of smart phones are not hindrances for teachers to engage themselves in m-learning. Findings of this research will help in designing and implementing $\mathrm{m}$ learning system for providing ICT training to the public school teachers in KP (Pakistan). This will also be significant in providing quality education to the public school students.
\end{abstract}

Keywords: teachers' willingness, ICT, mobile learning, teachers' training, public school education

\section{Introduction}

Twenty-first century has revealed many technological changes in various fields of life and the world has experienced many breakthroughs and innovations with the use of Information and Communication Technology (ICT). As education is the backbone of all aspects of life, the diffusion of technologies has also affected the educational sector. Conventional teaching and learning approaches are insufficient to fulfill the expectations of today's learners. ICT is the powerful tool for collecting, distributing, processing, managing and transferring information for Teaching and Learning Process (TLP). These technologies include radio, television, computers, telephone, smart phones, tablets, digital whiteboards and DVDs [1]. Learning is a continuous process and it requires innovative tools and techniques to get the updated information. Various ICT tools not only help in obtaining the updated information but also enhance students' motivation towards learning [2].

The use of ICT is not only extending educational opportunities to the rural and the urban population but also to the ethnic minorities, disabled persons and old people as well. 
One of the important features of ICT is its ability to surpass time and space. ICT can provide asynchronous learning anywhere, anytime. ICT based education delivery through radio and television programs also dispenses with the availability of all learners and instructors to be present in one physical location. Moreover, video conferencing technologies enable instructions to be received simultaneously by multiple, geographically dispersed learners, that is, synchronous learning [3]. ICT has the great potential for developing countries to improve the quality of education. It facilitates the acquisition of knowledge and provides opportunities for developing countries to enhance the educational system, improve the policy formulation and execution. The greatest hardship faced by the citizens of these countries is their isolation in terms of knowledge. ICT made possible to reduce this sense of isolation by having access to knowledge in several ways [4]. However, the fact about the Digital Divide means the gap between those who have access to the new technologies and those who are deprived of it, is very large and it is extremely challenging to integrate ICT at various levels of education. Failure to meet the challenge would increase the knowledge gap; consequently, there would be further inequalities in the existing economic and social systems [5].

\section{Research Problem}

\subsection{Research Background}

Quality education is an investment for the better future. One has to be very particular about his investment in educational process. The global trend of the twenty first century about the use of technologies in education has a great share in this investment. Schools are not just buildings rather these are institutions for knowledge and information. Students of the new generation have the right to acquire quality education and to equip themselves with the new ICT tools during learning. The platform of education perfects the educators which is very important for the enhancement of students' capabilities. If teachers do not take the initiative for professional development, it is difficult to achieve the creative spirit of the students.

Use of radio for education purpose started in 1930s, although it is a good source of information for education purpose, but to keep all listeners attentive throughout the program is not possible. Thus, television solved this problem during 1960s by providing visual aspects besides sound as well. It eased the work of teachers by providing visual aspects to make their students learn about the difficult concepts. With the advancement in technologies, radio and TV were replaced by computers, internet, DVDs. During twentyfirst century, introduction of handheld devices like tablets, laptops and smart phones paved the way for educators to make use of them in classes. Being portable and flexible, smart phones are the most suitable options for teachers around the world to use them in their classes.

There are about 30 million smart phones users in Pakistan and approximately 27 million people are using 3G mobile internet facility. The government of Pakistan is not only trying to make use of mobile phones for fighting against dengue, pest control on crops and managing waste, but also increases awareness in public about highlighting the corrupt and poor performing officials.

Pakistan, being a developing country, is far behind in the use of ICT in education system that is resulting in creating the knowledge gap and Digital Divide. This has an adverse effect on the social system and economic development of the country. It is necessary for the government of Pakistan to provide quality education to all the citizens not only to meet the international standards but also to enhance the economic development of the country by producing skilled workforce. Thus, it is necessary for students to get acquainted with the ICT skills and knowledge to compete with the ever changing world. It will also help in reducing the knowledge gap between the students of 
Pakistan and the rest of the world. This can be achieved by providing ICT training to the public school teachers. According to the educational policy of 2009 education reform is the agenda of government of Pakistan. Education system of Pakistan has many problems which include lack of uniform education system, curriculum, and medium of instruction; however, teachers' training is the main problem. Teacher training institutes are providing training to the public school teachers without focusing on the use of ICT. Moreover, due to geographical constraints, lack of infrastructure, shortage of electricity and non availability of internet, use of ICT is not possible in the remote areas of Pakistan. Therefore, we believe that the use of smart phones as a tool by the public school teachers in the class is a feasible solution. Government of KP Province has taken some initiatives towards the integration of ICT in public schools. There are 28,500 primary and secondary public schools, out of which only 500 secondary schools have IT laboratories with only 15 computers in each laboratory. Moreover, there are 123,380 public school teachers (male+ female) and 2500 secondary school teachers are being provided with tablets on the basis of performance (www.kpese. gov.pk) Although ICT is equally important at all levels of public education, however, students' exposure at early stage may enhance their mental development, abstract thinking, creativity, imagination, and social abilities that will be fruitful in their future.

The use of ICT using smart phones is somewhat revolutionary step for the public school teachers. Due to the lack of ICT training, most of the teachers are unfamiliar with the use of computers. In the past, some ICT trainings using computers were conducted but they were failed to achieve the desired goal.

The main reason of failure was the in-adaptive human nature after certain age. Computers appeared as new and complicated things for them and most of the teachers showed inability to learn it.

The recent hype in smart phones shows a hope of success. Learning from our past experience, we propose to use smart phones to promote the use of ICT to enhance the teaching experience. The use of smart phone has already been accepted by the major portion of society. The recent $3 \mathrm{G}$ and $4 \mathrm{G}$ technologies open new possibilities and services with endless opportunities. It also gives a hope to be accepted by the public school teachers to promote ICT in education.

Being infant, use of mobiles is in very early stage of success in education so it is very crucial to know about the willingness of users before designing m-learning system and implementing it. The studies carried out by some researchers in Pakistan regarding the use of mobiles in education were about the perception and readiness of students of higher education system. No such research regarding readiness of teachers about the use of mobiles is available especially by public school teachers. Teacher training is very crucial for the improvement of the quality education, but to organize teachers at a fixed place and at a fixed time is really hard due to reasons such as heavy workload at schools, family problems, geographical constraints and other social problems. With the rapid development of mobile technologies, decreasing prices and their increasing popularity, $\mathrm{m}$ learning has become an effective mean to solve the problem of providing training to teachers at their workplace and at any time. Thus, it is very important to investigate the perception of public school teachers for ICT based training by using smart phones.

\subsection{Purpose of the Study}

As mentioned earlier, there are certain limitations in providing quality education in Pakistan. There can be number of solutions to overcome this problem but for the successful implementation of any plan it has to be accepted by the masses. The purpose of this study is to find out public school teachers' willingness about the use of ICT in their classes by using their smart phones in the KP province of Pakistan. For the quantitative survey, a questionnaire was designed. About 600 questionnaires were distributed in the 
various districts of KP province covering primary and secondary government schools and 524 questionnaires were received back.

\section{Literature Review}

Many researchers have pointed out the importance of ICT in education. Teachers and learners no longer have to rely solely on printed books and other materials in physical media housed in libraries and available in limited quantities, for their educational needs. With the internet and World Wide Web, a wealth of learning materials in almost every subject and in a variety of media can now be accessed from anywhere at any time of the day and by an unlimited number of people. This is particularly significant for many schools in developing countries that have limited and outdated library sources. ICT also facilitates access to resource persons, mentors, experts, researchers, professionals and peers all over the world [6]. For the developed world, the definition of literacy has been changed as the ability to access and analyze the information available online [7].

Role of school principals in bringing about technological change is inevitable. Principals are the leaders of change, supporters of the professional development of teachers and the beginners of ICT use in schools. Thus, the provision of software or equipments and acquiring computer skills is not the successful implementation of ICT in schools rather supporting, empowering and influencing teachers in their engagement with the students' learning is indeed the successful implementation of ICT [8]. A shift from industrial age to knowledge economy requires a systematic change in public schools that is ongoing professional development of principals and teachers, equity of access and successful implementation of technological innovations in classrooms [9]. ICT enabled curriculum is fundamental to educational reforms. For the useful teaching and learning process, educational institutions in the countries of the world need to change their curriculum and train their teachers to use the new tools effectively in their classes as the professional ability of teachers is crucial to education development [10]. It is the job of the school administration and teachers how to apply ICT based curriculum in their classrooms. Policy makers and politicians will determine the potential of ICT in education but more importantly teachers can opt for innovative teaching practices and new organizational framework supported by new technologies [7].

Western countries were the pioneers in bringing about educational reforms by the integration of ICT in education. In the United States and the European countries, decades of eighties and nineties were the time period of change in their educational system. These transformations in the institutions enhanced the need for the promotion of teachers' training. Researchers highlighted that through in service training, the chances to gain expertise in their profession increase in order to meet the demands of the technological era [11]. Therefore, ICT skills are the most effective means of professional development and an answer to the new technological era's requirements [12].

Use of technologies in schools is not possible without teachers. They organize the team of professionals that operate the educational system so the in service trainings of these professionals will help them to meet the new challenges. Consequently, these lifelong learners will help to enhance the capabilities of primary and secondary school pupils. There is a great need of teachers' ICT based training programs to be harmonized with the technological era and to reduce the inequality between the public and private institutions [11]. Sharing of knowledge neither can be forced nor can be controlled; therefore technology is important for sharing of knowledge among members of various organizations. ICT help organizations to be innovative and efficient by making knowledge visible and providing means to remove communication barriers irrespective of space and time [13]. As stated earlier, teachers are the key persons for bringing about pedagogical change in education and can help in changing the teaching and learning scenario from teacher-centered towards the learner-centered one. Introducing technology 
alone into the classroom will not change the teaching process; in order to bring pedagogical change about using ICT in class it is necessary to get teachers familiarized with ICT and enable them to have regular access to ICT technologies [14]. In the era of information and technology there is a remarkable change in the teaching and learning process from individual learning to community learning. While applying ICT, students' collaborative learning is enhanced, especially competition and group rival increases and it has a least effect on students' assimilative writing and reading. Introducing new machines in the classroom is not the sole purpose of the use of ICT rather a shift from traditional teaching methods to the new teaching and learning process [15]. The need of ICT for teachers and students is not only for better teaching and learning process but also for their countries development. Moreover, teaching content should be connected to the outside world apart from the textbooks to make students aware of the life learning [16]. The collaborative training projects are necessary for in service teachers to create a group of pedagogical knowledge and experience and make accessible through the internet for other teachers as well. Seminars and virtual workshops will enhance the technological competencies of teachers that will help them to utilize ICT tools in their respective curricula [17]. ICT has a great potential to improve the quality of teaching, learning process and the management of education system. However, certain factors should be taken into account while using different technologies in imparting knowledge like sociocultural, economic and geographical background of the learners, as these factors may influence their ability to adopt new technologies. Providing quality education to the citizens is the main purpose of all educational institutions, and teachers are the key persons in enhancing the quality education and bringing about educational reforms [18].

The concept of distance learning started during 1960s which include the use of audio/video tapes for recording lectures or delivering lectures through live radio or television programs. These were replaced by the digital electronic tools and media with the emergence of World Wide Web and the world came to know about the new concept of electronic learning or e-learning. With the advancement of technologies the use of mobiles, laptops and tablets increased. The introduction of various new applications in the smart phones led the researchers to think about the use of smart phones for the teaching and learning process. The nature of education system has been altered with the use of wireless phones, handheld devices and improving internet capabilities. The advanced version of e-learning is mobile learning or m-learning that has been originated from distance education. In some developing countries the fact about using ICT is that the classrooms look like as they were hundred years ago. Conventional teaching is practiced by most of the teachers and textbooks are the only source of teaching and learning in several schools [19]. The motivation for the use of technologies begins if teachers are well versed about the use of these technologies in their daily practice. Teachers' attitude towards the use of these advanced technologies will help in the integration of these resources in teaching and learning [20].

Introduction of new advanced features in mobile phones like making audio/video phone calls, recording audios/videos, capturing pictures, storage of data, accessibility to internet coupled with mobiles sets decreasing cost made possible for huge number of people to use them. This led to make use of these mobile sets for education purpose. The success of m-learning depends upon the teachers if they are well versed in using them and it is also pre requisite for educationists for developing m-learning content.

M-learning is flexible and it provides the opportunities for learners to access information at the time of need by using handheld devices via wireless network. Technology should be the part of teacher training program so that pre-service teachers can experience the use of ICT in various subjects. Teacher training institutes must include ICT literacy and basic computer skills as part of teaching and learning [21]. Mobile devices, being ubiquitous and flexible, are worth for education purpose. As it is difficult for most of the educational institutions to acquire IT resources, therefore mobile devices 
are the feasible and economical solution of this problem. Many pilot projects are already in practice in some developing countries and are successful as well. Therefore, now it's time for the respective governments to take serious measures for implementation of $\mathrm{m}$ learning for teaching and learning [22]. The usability and accessibility play a vital role in the acceptance, use and giving value to the desired system. Learners have different learning profiles and knowledge skills, therefore before designing a model for m-learning, learners' capabilities and acceptance towards the self-adaptive system should be kept in mind. Therefore customized features should be provided to meet the needs of different learners [23].

Successful implementation of m-learning depends upon the readiness of learners. In the distance learning, as the learner is away from the mentor or counselor, the willingness to self manage and self direct is the success of distance education. Learners become incharge of their own learning so the use of mobiles in m-learning depends upon the learners' attitude towards learning and giving value to their education. Although digital learning materials are available but learners did not take full advantage of using these materials through their mobiles. Currently m-learning has not attained its full potential and the gap exists between the offered materials and the used information [24]. Due to technical challenges, adoption of e-learning services to m-learning is difficult; hence, the successful adoption of m-learning depends upon the willingness of users [25].

Barriers to the use of mobile sets in education were classified into first order (lack of resources, training, time and support) and second order (resistance to change, lack of confidence and motivation towards m-learning) by the authors in [20] to find out teachers' willingness and attitude towards m- learning. They explored that schools should provide resources needed for the use of ICT in classes. In addition, it is very important to provide time and opportunities for professional development of teachers by introducing easy accessible solutions so that teachers can enhance their confidence in using mobile technology in their teaching practice. Boosting the best options for innovative learning methods by the combination of computer assisted methods along with the mobile technologies is referred to as b-learning. It is not an easy task to provide complete training to teachers through mobile phones because of reduced screen size; however, it is very important in receiving information at any place and at any time [26].

Role of policy makers and stakeholders in successful implementation of ICT in education cannot be neglected, because any change in policy means change in the scenario of the education system.There is a need for the national policy revision regarding m-learning. If education is decentralized, it is also suggested to provide structure and guidelines for m-learning while local policies of the respective areas take initiatives in the direct implementation of these policies. M-learning can become part of education if current ICT strategies for education include digital learning materials, guidelines for teachers and this will also help in meeting the essential Education for All (EFA) goal of providing quality education to all learners across the world [27].

\section{Methodology}

For the provision of quality education to the public school students, it is necessary to train teachers with the use of ICT tools for various subjects in a class. However, for successful implementation of ICT in education it is necessary to be accepted by the teachers. For this purpose this research is carried out in the KP province of Pakistan to ascertain teachers' willingness about the use of ICT through m-learning. The survey consisted of participants of the public school teachers (primary and secondary) of KP, Pakistan.

The questionnaire is divided into three sections. Demographic profile of teachers was included in the first section, questions related to teachers' knowledge of ICT and perception about using mobile technology in their respective subjects were included in the 
second section. The third section consisted of questions related to the constraints involved in using mobiles, financial issues hindering the way in the implementation of m-learning in public schools. Five point Likert scale was used for all questions. Questionnaires were given directly to teachers in their schools and were received back once they filled it. Some questionnaires were posted to teachers in the remote areas of the province.

This survey was carried out in January and February 2016, for a period of two months. Total 600 questionnaires were distributed among the teachers of primary and secondary schools of various districts of KP province, Pakistan and 524 responses were received back.

\section{Findings}

\subsection{Teachers' Demographic Profile}

Table 1. Teachers' Demographic Profile

\begin{tabular}{|c|c|c|c|}
\hline & $\begin{array}{c}\text { Teacher Demography } \\
\text { and background } \\
(\mathrm{N}=524) \\
\end{array}$ & Frequency & Percentage $(\%)$ \\
\hline \multirow{3}{*}{ Gender } & & & \\
\hline & Male & 252 & 48.1 \\
\hline & Female & 272 & 51.9 \\
\hline \multirow{5}{*}{ Age Range } & & & \\
\hline & $20-30$ & 71 & 13.5 \\
\hline & $31-40$ & 198 & 37.8 \\
\hline & $41-50$ & 178 & 34 \\
\hline & $51-60$ & 77 & 14.7 \\
\hline \multirow{5}{*}{$\begin{array}{l}\text { Educational } \\
\text { Background }\end{array}$} & & & \\
\hline & FA/F.SC & 80 & 15.3 \\
\hline & Bachelor & 139 & 26.5 \\
\hline & Masters & 292 & 55.7 \\
\hline & M.Phil & 13 & 2.5 \\
\hline \multirow{7}{*}{ Years of service } & & & \\
\hline & $1-5$ & 83 & 15.8 \\
\hline & $6-10$ & 45 & 8.6 \\
\hline & $11-15$ & 64 & 12.2 \\
\hline & $16-20$ & 102 & 19.5 \\
\hline & $21-25$ & 156 & 29.8 \\
\hline & above 26 & 74 & 14.1 \\
\hline \multirow{8}{*}{ Subject of teaching } & & & \\
\hline & English & 75 & 14.3 \\
\hline & Urdu & 89 & 17 \\
\hline & Mathematics & 68 & 13 \\
\hline & Science & 65 & 12.4 \\
\hline & Islamiyat & 71 & 13.5 \\
\hline & S.Studies & 51 & 9.7 \\
\hline & Others & 105 & 20 \\
\hline
\end{tabular}

Table 1, shows that among the 524 respondents there were more females, $272(51.9 \%)$ as compared to males, 252 (48.1\%). The majority of teachers were aged between 31-40 years, $198(37.8 \%)$ having teaching experience of 21-25 years, $156(29.8 \%)$. The highest level of education of the majority of the participants was Masters Degree comprised of 292 teachers $(55.7 \%)$ followed by Bachelors Degree, 139 teachers (26.5\%). Participants, teaching various subjects like English, Urdu, Mathematics, Science, Islamiyat with a very 
less difference in percentage while majority of the participants teaching other subjects (Biology, Physics, Chemistry) have high percentage i.e. $20 \%$.

\subsection{Perception of Teachers about ICT and m- Learning}

Teachers' perception and attitude towards using ICT and mobile learning was dealt in section 2. There were total 17 questions and respondents had to fill these questions against five point Likert scale. These questions were divided into three groups; teachers' attitude towards using ICT in the class, their perception about ICT based courses and knowledge about mobile learning.

Table 2. Teacher's Attitude Towards using ICT in the Class

\begin{tabular}{|c|c|c|c|c|c|c|}
\hline No. & Statements & $\begin{array}{c}\text { SA } \\
(\%)\end{array}$ & $\begin{array}{c}\text { A } \\
(\%)\end{array}$ & $\begin{array}{c}\mathbf{N} \\
(\%)\end{array}$ & $\begin{array}{l}\text { DA } \\
(\%)\end{array}$ & $\begin{array}{l}\text { SDA } \\
(\%)\end{array}$ \\
\hline & Teachers' attitude towards using ICT in the class & & & & & \\
\hline A1 & Use of ICT (computer/mobile) in class appeal to me. & 31.5 & 44.1 & 13.2 & 9.5 & 1.7 \\
\hline A2 & I am confident enough to use ICT in my class. & 14.9 & 53.1 & 18.3 & 11.8 & 1.9 \\
\hline A3 & ICT should be used for all subjects. & 15.5 & 48.5 & 17 & 16.6 & 2.5 \\
\hline A4 & ICT help in providing guiding material for the lessons/lectures & 22.3 & 62.2 & 7.1 & 3.4 & 5 \\
\hline \multirow[t]{2}{*}{ A5 } & $\begin{array}{l}\text { ICT help me to improve the knowledge and academic } \\
\text { performance of students. }\end{array}$ & 30.7 & 53.4 & 4.8 & 4.6 & 6.5 \\
\hline & Teachers' perception about ICT based courses & & & & & \\
\hline B1 & $\begin{array}{l}\text { I am willing to get ICT training if such training is provided by } \\
\text { Govt. }\end{array}$ & 43.9 & 36.5 & 3.4 & 12.2 & 4 \\
\hline B2 & ICT based courses should be included in teachers training. & 26 & 52.7 & 1.5 & 11.8 & 8 \\
\hline B3 & Lack of Government interest to provide ICT training to teachers. & 15.6 & 49.6 & 22.5 & 6.3 & 5.9 \\
\hline B4 & $\begin{array}{l}\text { Absence of private teacher training institutes offering ICT based } \\
\text { training. }\end{array}$ & 4.2 & 76.9 & 15.1 & 3.8 & 0 \\
\hline B5 & $\begin{array}{l}\text { Teacher training institutes are far away from my work place/ } \\
\text { home. }\end{array}$ & 16.8 & 46.2 & 17.4 & 19.7 & 0 \\
\hline \multirow[t]{2}{*}{ B6 } & $\begin{array}{l}\text { I cannot stay away for a long time from my work place/home for } \\
\text { acquiring ICT training }\end{array}$ & 25.4 & 43.1 & 10.9 & 20.6 & 0 \\
\hline & Teachers' knowledge on mobile learning & & & & & \\
\hline $\mathrm{C} 1$ & I know what mobile learning is about. & 15.5 & 44.8 & 19.3 & 19.1 & 1.3 \\
\hline $\mathrm{C} 2$ & I feel that mobile learning is helpful in learning ICT skills. & 16.4 & 54 & 7.3 & 14.3 & 8 \\
\hline $\mathrm{C} 3$ & $\begin{array}{l}\text { Mobile learning will save my time by learning new skills at my } \\
\text { work place or home. }\end{array}$ & 12.6 & 67.2 & 4.8 & 11.8 & 3.6 \\
\hline $\mathrm{C} 4$ & $\begin{array}{l}\text { I would prefer mobile learning over conventional method of } \\
\text { learning. }\end{array}$ & 10.3 & 63.5 & 9.7 & 14.1 & 2.3 \\
\hline $\mathrm{C} 5$ & Mobile learning is easier than computer learning. & 12.2 & 59.9 & 7.4 & 16.4 & 4 \\
\hline C6 & Learning ICT skills through smart phones will make my life easy. & 10.9 & 68.5 & 6.1 & 11.6 & 2.9 \\
\hline
\end{tabular}

There were five statements about the use of ICT in class and Table 2, indicates that $53.1 \%$ of participants were willing towards the use of ICT in the class. About $48.1 \%$ of teachers taking various subjects showed their willingness towards the use of ICT through $\mathrm{m}$-learning. Therefore m-learning is not limited to certain subjects. Regarding the provision of guiding material, innovative ways of teaching with the use of ICT, about $62.2 \%$ of teachers were agreed on it. Moreover, $53.4 \%$ of teachers were agreed on the statement that new technologies help them to improve knowledge and motivation of students towards learning. 
Table 2, shows that $52.7 \%$ teachers were agreed that ICT based courses should be included in teachers' training. About $49.6 \%$ of participants pointed out that there is a lack of government interest for the provision of ICT trainings to teachers. A great majority of teachers $(76.9 \%)$ were agreed that there are no private teacher training institutes offering ICT based courses. About $46.2 \%$ of respondents are agreed that teacher training institutes are far away from their workplace/home, and $43.1 \%$ of teachers were agreed that they cannot stay away from their home/workplace for a long time for acquiring ICT training.

Table 2, also indicates that in terms of teachers' knowledge about m-learning, $44.8 \%$ of participants were aware about it and $67.2 \%$ of respondents were agreed on the statement that"mobile learning will save my time by learning new skills at my workplace/home". Hence $59.9 \%$ of them were agreed on that $\mathrm{m}$ - learning is easier than computer learning. Moreover, $68.5 \%$ of teachers were agreed on learning ICT through smart phones.

Teachers' response pointed out the willingness of teachers to the use of ICT in their classes; however, there is lack of training courses focusing on ICT. Furthermore, those training institutes are very limited and often too far away to be attended conveniently. Mlearning can provide an effective solution to these existing problems. Above all, teachers are willing to adapt to m-learning, which pave a path towards the successful implementation of m-learning.

\subsection{Constraints/Problems about the Implementation of m-Learning}

Teachers' constraints about using smart phones and financial problems were discussed in section 3. There were eight questions and participants were asked to answer these questions against five point Likert scale. These questions were divided into two groups; smart phone constraints and financial constraints.

Table 3, shows that $45.4 \%$ of participants have smart phones. Moreover, $47.3 \%$ of respondents can use internet on their smart phones while $26.1 \%$ of teachers showed lack of interest. About $50 \%$ of teachers were agreed for $\mathrm{m}$ - learning and $54 \%$ of them were agreed to upgrade their mobiles for $\mathrm{m}$ - learning.

Regarding the financial constraints, Table 3, indicates that $44.7 \%$ of teachers were willing to pay extra money for learning ICT skills through smart phones and $19.7 \%$ were disagreed, while $15.3 \%$ remained neutral. About $44.8 \%$ of teachers were agreed that mobile company charges for internet are affordable and $27.7 \%$ were not agreed. Average number of teachers $(40.5 \%)$ were ready to pay the cost of Internet in mobiles, $21.9 \%$ were neutral while $30.3 \%$ were not agreed.

Table 3. Constraints/Problems about the Implementation of $m$-Learning

\begin{tabular}{|c|c|c|c|c|c|c|}
\hline No. & Statements & $\begin{array}{l}\text { SA } \\
(\%)\end{array}$ & $\begin{array}{c}\text { A } \\
(\%)\end{array}$ & $\begin{array}{c}\mathbf{N} \\
(\%)\end{array}$ & $\begin{array}{l}\text { DA } \\
(\%)\end{array}$ & $\begin{array}{l}\text { SDA } \\
(\%)\end{array}$ \\
\hline & Smart phones constraints. & & & & & \\
\hline D1 & I have a smart phone. & 17 & 45.4 & 4 & 31.3 & 2.3 \\
\hline D2 & I know how to use internet on my smart phone. & 16 & 47.3 & 9.2 & 26.1 & 1.3 \\
\hline D3 & $\begin{array}{l}\text { I want to learn how to use my smart phone for mobile } \\
\text { learning. }\end{array}$ & 14.5 & 50 & 11.5 & 15.6 & 8.4 \\
\hline \multirow[t]{2}{*}{ D4 } & $\begin{array}{l}\text { I am ready to upgrade my smart phone if training institutes } \\
\text { are going to introduce ICT based training courses. }\end{array}$ & 20.2 & 54 & 6.1 & 14.7 & 5 \\
\hline & Financial constraints & & & & & \\
\hline E1 & $\begin{array}{l}\text { I am ready to pay extra money for learning ICT skills } \\
\text { through mobile learning for my professional development. }\end{array}$ & 10.9 & 44.7 & 15.3 & 19.7 & 9.5 \\
\hline E2 & The mobile company charges for internet are affordable. & 4.2 & 44.8 & 19.7 & 27.7 & 3.6 \\
\hline E3 & $\begin{array}{l}\text { I can afford the cost of Wi-Fi (Internet) in my mobile for } \\
\text { mobile learning. }\end{array}$ & 4 & 40.5 & 21.9 & 30.3 & 3.2 \\
\hline
\end{tabular}


E4 I am ready to pay the cost of communicating in the mobile learning courses with the tutor or other colleagues.

\begin{tabular}{l|l|l}
6.5 & 45.6 & 19.7
\end{tabular}

Although not majority of teachers have smart phones at the moment but the growing trend and decreasing prices of smart phones lead us to predict that in near future most of the teachers will have smart phones. Furthermore, government can provide smart phones to teachers for the promotion of m-learning in education sector.

Table 4. Correlations Analysis

\begin{tabular}{|ll|c|c|c|c|c|}
\hline & $\begin{array}{l}\text { Teachers' } \\
\text { attitude }\end{array}$ & $\begin{array}{l}\text { Teachers' } \\
\text { perception }\end{array}$ & $\begin{array}{c}\text { Teachers } \\
\text { knowledge }\end{array}$ & $\begin{array}{l}\text { Smart phone } \\
\text { constraint }\end{array}$ & $\begin{array}{c}\text { Financial } \\
\text { constraint }\end{array}$ \\
\hline Teachers & Pearson Correlation & 1 & $.562^{* *}$ & $.665^{* *}$ & $.473^{* *}$ & $.389^{* *}$ \\
attitude & Sig. (2-tailed) & & .000 & .000 & .000 & .000 \\
& $\mathrm{~N}$ & 524 & 524 & 524 & 524 & 524 \\
Teachers & Pearson Correlation & $.562^{* *}$ & 1 & $.480^{* *}$ & $.442^{* *}$ & $.212^{* *}$ \\
perception & Sig. (2-tailed) & .000 & & .000 & .000 & .000 \\
& $\mathrm{~N}$ & 524 & 524 & 524 & 524 & 524 \\
Teachers & Pearson Correlation & $.665^{* *}$ & $.480^{* *}$ & 1 & $.550^{* *}$ & $.534^{* *}$ \\
knowledge & Sig. (2-tailed) & .000 & .000 & & .000 & .000 \\
Smart & Pearson Correlation & 524 & 524 & 524 & 524 & 524 \\
phone & Sig. (2-tailed) & $.473^{* *}$ & $.442^{* *}$ & $.550^{* *}$ & 1 & $.404^{* *}$ \\
constraint & $\mathrm{N}$ & .000 & .000 & .000 & .000 \\
& Pearson Correlation & 524 & 524 & 524 & 524 & 524 \\
Financial & Sig. (2-tailed) & $.389^{* *}$ & $.212^{* *}$ & $.534^{* *}$ & $.404^{* *}$ & 1 \\
constraint & $\mathrm{N}$ & .000 & .000 & .000 & .000 & \\
& & 524 & 524 & 524 & 524 & 524 \\
\hline
\end{tabular}

${ }^{\star *}$. Correlation is significant at the 0.01 level (2-tailed).

\section{Correlation Analysis}

Correlation analysis is performed to show the degree of association among the variables. Results of correlation analysis are shown in Table 4. The table indicates the relationship among all variables. The results indicate teachers' attitude towards using ICT has a significant relationship with teachers' perception about ICT training $(r=0.562, p<$ 0.01). These values confirm that teachers' attitude has a positive relationship with teachers' perception about ICT training. The relationship between teachers' knowledge about m-learning and teachers' attitude is also very strong with $\mathrm{r}=0.665, \mathrm{p}<0.01$. Teachers' attitude towards using smart phones for ICT training does not show any significant constraint as the value $r=0.473, p<0.01$ is very strong. Teachers' attitude has a significant and positive relationship with financial constraints $(r=0.389, p<0.01)$. Overall correlation analysis indicates all variables have a significant and positive relationship.

\section{Conclusion/Suggestions}

The use of advanced technologies has brought significant changes in various fields of life especially in education system. ICT based education is playing a significant role in the economic development of the country by producing skilled workforce. Developed countries are providing quality education to all the citizens but developing countries are lagging behind in providing quality education to their citizens. This is resulting in knowledge gap and Digital Divide and is also affecting the economic growth of the country.

Low budget for education, lack of infrastructure and especially lack of the provision of ICT training to the public school teachers are the main challenges in providing quality education in Pakistan. Provision of ICT training through m-learning is the cost effective solution for this problem. For the successful implementation of any newly introduced 
system, it is important to be accepted. For this purpose teachers' willingness about using smart phones for ICT based training in KP province (Pakistan) is presented in this paper. Overall, more than average number of teachers showed positive attitude towards $\mathrm{m}$ learning. Although their knowledge about ICT and m-learning was average but they were enthusiastic towards bringing pedagogical change and students' learning according to the demand of technological era. Surprisingly, teachers were willing to bear the cost of internet in order to improve their teaching methodology with the help of m-learning. However, government support coupled with teachers' enthusiasm can significantly improve the teaching and learning environment. Findings of this study will be used as a basis for designing m-learning system for providing ICT training to the public school teachers of KP, Pakistan.

\section{References}

[1] S. Bidarian, S. Bidarian and A. M. Davoudi, "A Model for application of ICT in the process of teaching and learning", Procedia- Social and Behavioral Sciences, vol. 29, (2011), pp. 1032-1041.

[2] S. Hennessy, R. Deaney and K. Ruthven, "Pedagogic strategies for using ICT to support subject teaching and learning: An analysis across 15 case studies", Research Report, Cambridge: University of Cambridge, no. 03/1, (2003).

[3] J. Rahmani, N. Mvhdynya and G. H. Salimi, "The role of Educational Information and Communication Technology in Education", Journal of Azad University of Khorasgan, vol. 11, (2006), pp. 49-66.

[4] A. K. SuatCapuk, "A Decision of ICT Integration with Developed and Developing World Context Critical Perspectives, Procedia- Social and Behavioral Sciences, vol. 191, (2015), pp. 56-62.

[5] P. Hepp, J. E. H. Stroza, E. Laval and L. Rehbein, "Technology in schools: Education, ICT and the knowledge society", Washington, DC: World Bank, (2004).

[6] T. R. Guskey, "Professional Development and Teacher Change", Teachers and Teaching: theory and practice, vol. 8, no. 3-4, (2002).

[7] C. F. Webber," New technologies and educative leadership", Journal of Educational Administration", vol. 4, no. 2, (2003), pp. 119-123.

[8] A. H. K. Yuen, N. Law and K. C. Wong, "ICT implementation and school leadership: Case studies of ICT integration in teaching and learning", Journal of Educational Administration, vol. 41, no. 2, (2003), pp. $158-170$.

[9] L. Flanagan and M. Jacobson, "Technology leadership for the twenty-first century principal”, Journal of Educational Administration, vol. 41, no. 2, (2003), pp. 124-142.

[10] S. Moradi and A. Khalkhali, "Evaluation of the level of ICT integration and usage in teachers' curricula in Iranian schools", Multicultural Education and Technology Journal, vol. 2, no. 3, (2008), pp. 170-178.

[11] P. Giavrimis, S. Giossi and A. Papastamatis, "Teachers' attitude towards training in ICT: a critical approach", Quality assurance in Education, vol. 19, no. 3, (2011), pp. 283-296.

[12] S. Vosniadou, "Children, Schools and Computers", Gutenberg Publications, Athens, (2006).

[13] J. Rikala, L. Hiltunen and M. Vesisenaho, "Teachers'Attitudes, Competencies and Readiness to Adopt Mobile Learning Approaches," IEEE, (2014).

[14] L. Hortovanyi and A. Ferincz, "The impact of ICT on learning on-the-job", The Learning Organization, vol. 22, no. 1, (2015), pp. 2-13.

[15] K. Sipila, "No pain,no gain? Teachers implementing ICT in instruction", Interactive Technology and Smart Education, vol. 8, no. 1, (2011), pp. 39-51.

[16] A. Shrifi, M. N. Imani and F. Eslamieh, "Investigating the Role of Infornation \& Communication Technologies on Students' Collaborative Learning", Procedia- Social and Behavioral Sciences, vol. 83, (2013), pp. 932-936.

[17] F. O. Pineida,"Competencies for the $21^{\text {st }}$ Century: Integrating ICT to Life, School and Economical Development," Procedia- Social and Behavioral Sciences,vVol. 28, (2011), pp 54-57.

[18] A. B. Sanchez, J. J. M. Marcos, M. Gonzalez and H. G. Lin, "In service Teachers' attitude towards the use of ICT in the classroom", Procedia- Social and Behavioral Sciences, vol. 46, (2012), pp. 1358-1364.

[19] H. Rehman, "The Role of ICT in Distance and Open Education", Turkish Online Journal of Distance Education-TOJDE, ISSN 1302-6488, vol. 15, no. 4, Article 9, (2014).

[20] J. Rikala, L. Hiltunen and M. Vesisenaho, "Teachers'Attitudes, Competencies and Readiness to Adopt Mobile Learning Approaches," IEEE, (2014).

[21] C. C. Chao, "Evaluating Teachers' attitude towards the use of Wireless-Mobile Technologies in Supporting Learning: An Instrument Development study", Proceedings of the 2005 IEEE International Workshop on Wireless and Mobile Technologies in Education (WMTE'05), (2005).

[22] N. Mndzebele, "Teachers Readiness in the classroom: The Case of a Developing Country", International Journal of Information and Education Technology, vol. 3, no. 4, (2013). 
[23] S. Gounder, "What is the Potential Impact of Using Mobile Devices in Education?"Proceedings of SIG GlobDev Fourth Annual Workshop, Shanghai, China, (2011).

[24] G. Male and C. Pattinson, "Enhancing the quality of e-learning through mobile technology.A sociocultural and technology perspective towards quality e-learning applications," Campus-Wide Information System, vol. 28, no. 5, (2011), pp. 331-344.

[25] Y. Liu and S. Han and H. Li, "Understanding the factors driving m-learning adoption: a literature review," Campus-Wide Information Systems, vol. 27, no. 4, (2010), pp. 210-226.

[26] Y. S. Wang, M. C. Wu and H. Y. Wang, "Investigating the determinants and age and gender differences in the acceptance of mobile learning", vol. 40, no. 1, (2009).

[27] T. Magal-Royo, I. T. Montanana, J. L. G. Lopez and F. G. Alcalde, "New educative methods in the usage of audiovisual content in mobiles. Procedia- Social and Behavioral Sciences, vol. 2, (2010), pp. $4492-4496$.

[28] Y. Mehdipour and H. Zerehkafi, "Mobile Learning for Education: Benefits and Challenges. International Journal of Computational Engineering Research, vol. 03, no. 6, (2013).

\section{Authors}

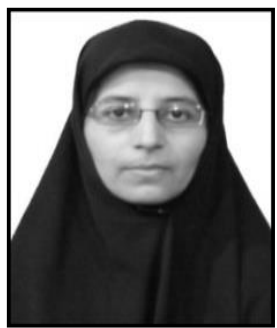

Shafaq Salam, is a Ph.D scholar at the School of Economics and Management, Beijing University of Posts and Telecommunications, Beijing, China. She worked at Beaconhouse School System, Peshawar, Pakistan as an education expert. Her areas of interests are education development and advanced technologies in education system

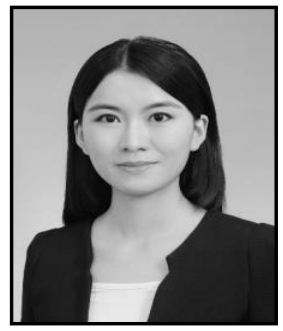

Mengke Yang, is recently doing her post-doctoral research work at Beijing University of Posts and Telecommunications, Beijing, China. She has received her $\mathrm{PhD}$ degree in management science and engineering from BUPT, and been involved in many scientific research including national key projects and enterprise consulting projects. Her major research interests include information technology management, e-commerce and logistics.

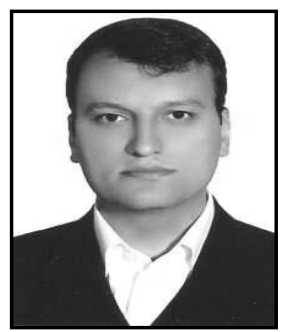

Mahmood Movahedipor, is a Ph.D scholarat the School of Economics and Management, Beijing University of Posts and Telecommunications, Beijing, China.He is also working in Academic Center for Education, Culture and Research (ACECR), Tehran, Iran. His areas of interests include supply chain management and logistics

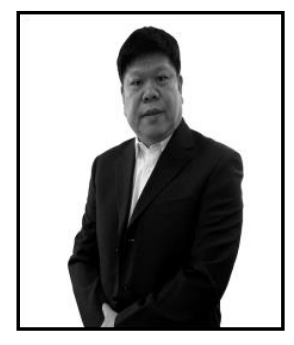

Zeng Jianqiu, obtained his Ph.D. degree from Cambridge University (England). He is a professor and a doctoral advisor in the School of Economics and Management of BUPT and also the Director of Information Economy and Competitiveness Research Center. Professor Zeng has also taken many social positions, including expert for Chinese Service Center, member of the International Team of Asian-pacific network operation and management forum, IEEE, CNOM and NOMS, Senior Consultant of China Mobile, Professor of China EMS and Tianjin Foreign Studies University, TEO of China Business Solution of Cambridge Science Park of Britain. His research areas are:competitiveness and IT industry development, enterprise consultancy and technological economic study. 